\title{
The Effect of Savings and Loan Cooperative Credit on Increasing Income of Damai Savings and Loan Cooperative (KSP) Members, Gangga District, North Lombok Regency
}

\author{
Handoyo Wirastomo ${ }^{1}$, Sulhan Hadi $^{2}$ \\ ${ }^{1,2}$ Universitas Muhammadiyah Mataram \\ ${ }^{1}$ handoyo.wirastomo@gmail.com ${ }^{2}$ sulhanhadi1212@gmail.com
}

\begin{abstract}
The Damai Savings and Loan Cooperative (KSP) is one of the savings and loan cooperatives in the North Lombok district. The main activities of savings and loan cooperatives are providing loans to members with an interest of $2 \%$ of the remaining principal of the loan, recording of financial receipts and expenditures has been carried out properly. Every financial receipt and expenditure has been proven and recorded in cash out and in. The Damai Savings and Loans Cooperative (KSP) is a cooperative that lends money to civil servants (PNS) and is returned by deducting employee salaries through a salary kit. This study aims to determine the effect of credit savings and loan cooperatives on increasing the income of members of the Damai savings and loan cooperative (KSP) in Gangga sub-district, North Lombok district. This research is a quantitative research. The variables of this research are savings and loan credit and the income of members of savings and loan cooperatives. The data source used in this study is the primary data source. The data collection technique used consisted of observation, interviews / interviews, documentation, literature study, questionnaires. The population in this study amounted to 267 people. And the sample in this study amounted to 50 people.

Keywords: Credit, Savings and Loan Cooperatives and Income.
\end{abstract}

\section{Pengaruh Kredit Koperasi Simpan Pinjam Terhadap Peningkatan Pendapatan Anggota Koperasi Simpan Pinjam (KSP) Damai Kecamatan Gangga Kabupaten Lombok Utara \\ ABSTRAK}

\begin{abstract}
Koperasi simpan pinjam (KSP) Damai adalah salah satu koperasi simpan pinjam yang ada di wilayah kabupaten Lombok utara. Kegiatan pokok koperasi simpan pinjam yaitu memberikan pinjaman kepada anggota dengan bunga sebesar $2 \%$ dari sisa pokok pinjaman, pencatatan penerimaan dan pengeluaran keuangan telah dilaksanakan dengan baik. Setiap penerimaan dan pengeluaran keuangan telah dibuktikan bukti dan dicatat pada kas keluar dan masuk. Koperasi simpan pinjam (KSP) Damai adalah koperasi yang meminjamkan uang kepada pegawai negeri sipil (PNS) dan dikembalikan dengan cara pemotongan gaji pegawai melalui kitir gaji. Penelitian ini bertujuan untuk mengetahui pengaruh kredit koperasi simpan pinjam terhadap peningkatan pendapatan anggota koperasi simpan pinjam (KSP) Damai kecamatan gangga kabupaten Lombok utara. Penelitian ini merupakan penelitian kuantitatif. Variable penelitian ini adalah kredit simpan pinjam dan pendapatan anggota koperasi simpan pinjam. Sumber data yang digunakan dalam penelitian ini adalah sumber data Primer. Teknik pengumpulan data yang digunakan adalah terdiri dari Observasi,interview / wawancara, dokumentasi, studi pustaka, kusioner (angket).populasi dalam penelitian ini berjumlah 267 orang. Dan sampel dalam penelitian ini berjumlah 50 orang.

Kata Kunci: Kredit, Koperasi Simpan Pinjam dan Pendapatan.
\end{abstract}




\section{PENDAHULUAN}

Koperasi sebagai gerakan ekonomi yang tumbuh dari masyarakat, lebih merupakan organisasi swadaya masyarakat yang lahir atas kehendak, kekuatan dan partisipasi masyarakat dalam menentukan tujuan, sasaran kegiatan, serta pelaksanaannya. Keberadaan koperasi sebagai wadah untuk mewujudkan kesejahteraan bersama bagi seluruh rakyat Indonesia.Koperasi sebagai gerakan ekonomi yang tumbuh dari masyarakat, lebih merupakan organisasi swadaya masyarakat yang lahir atas kehendak, kekuatan dan partisipasi masyarakat dalam menentukan tujuan, sasaran kegiatan, serta pelaksanaannya. Keberadaan koperasi sebagai wadah untuk mewujudkan kesejahteraan bersama bagi seluruh rakyat Indonesia. Pada masa sekarang ataupun yang akan datang, masyarakat Indonesia khususnya kalangan menengah kebawah masih membutuhkan koperasi. Alasan utama kebutuhan tersebut adalah dasar pemikiran ekonomi dalam konsep pendirian koperasi, seperti untuk meningkatkan kekuatan penawaran, meningkatkan skala usaha bersama, pengadaan pelayanan yang selama ini tidak ada, serta pengembangan kegiatan lanjutan (pengolahan, pemasaran, dan sebagainnya) dari kegiatan anggota. Alasan lainnya adalah terdapat peluang yang diberikan koperasi untuk mengembangkan potensi usaha tertentu (yang tidak berkaitan dengan usaha anggota) atau karena memanfaatkan fasilitas yangdisediakan pihak lain (pemerintah) yang mensyaratkan kelembagaan koperasi, sebagaimana bentuk praktek pengembangan koperasi yang telah dilakukan.

Dengan demikian, koperasi sangat berperan penting dalam mewujudkan tujuan pembangunan negara Indonesia dalam mensejahterakan ekonomi rakyat Indonesia. Tujuan koperasi adalah untuk meningkatkan kesejahteraan anggota pada khususnya dan masyarakat pada umumnya, sekaligus sebagai bagian yang tidak terpisahkan dari tatanan perekonomian nasional yang demokratis dan berkeadilan, hal ini dijelaskan dalam Undang - Undang Republik 

Indonesia No. 17 Tahun 2012 Pasal 4 tentang Perkoperasian. Koperasi dapat bergerak kedalam segala kegiatan ekonomi tetapi hal ini tidak berarti bahwa suatu koperasi dapat bergerak dalam kegiatan - kegiatan yang terlepas dari kepentingan - kepentingan anggota koperasi yang bersangkutan. Koperasi mempunyai peran penting dalam membantu masyarakat golongan menengah kebawah dalam meningkatkan kesejahteraan perekonomiannya. Operasional koperasi diarahkan agar mampu mendorong laju pertumbuhan ekonomi dengan tetap memberikan perhatian dan meningkatkan perannya dalam membantu anggota koperasi untuk meningkatkan taraf hidup ke arah yang lebih makmur. Seiring dengan perkembangan zaman, koperasi juga ikut berkembang kearah yang lebih maju. Akan tetapi perkembangan koperasi itu tidak serta merta merubah prinsip serta fungsi awal dari pembentukan koperasi. Salah satu bidang usaha produk dari koperasi adalah pemberian kredit. Kredit didalam koperasi adalah semua jenis pinjaman uang yang harus dibayar kembali bersama bunganya oleh peminjam serta adanya kesepakatan pelunasan pinjam meminjam. 


\section{Jumlah anggota yang menerima kredit Koperasi Dan Jumlah Kredit Koperasi Di Kabupaten Lombok Utara Periode Tahun 2015-2019}

\begin{tabular}{|l|l|l|}
\hline \multirow{2}{*}{ Tahun } & \multicolumn{2}{|l|}{ KSP Damai } \\
\cline { 2 - 3 } & Anggota Yang menerima kredit & Jumlah kredit \\
\hline 2015 & 267 & $4,010.948,772$ \\
\hline 2016 & 256 & $3,741,438,477$ \\
\hline 2017 & 224 & $3,260,417,232$ \\
\hline 2018 & 219 & $2,995,247,151$ \\
\hline 2019 & 214 & $2,685,518,000$ \\
\hline
\end{tabular}

Dari tabel diatas dapat dilihat bahwa selama periode tahun 2015-2019 jumlah anggota yang menerima kredit pada KSP Damai berfluktuasi. Dimana jumlah anggota yang menerima kredit paling banyak pada tahun 2014 yaitu sebanyak 267 orang dan terendah tahun 2018 yaitu sebanyak 214 orang dengan rata-rata penurunan pertahunnya adalah $-4 \%$ Rata-rata pendapatan dan omset usaha responden mengalamimengalami penurunan setelah menerima kredit hal ini disebabkan karena pencatatan transaksi keuangan terkadang tidak tepat waktu hal ini karena disebabkan karena kesibukan yang dihadapi pengurus hal ini dapat diatasi dengan kerjasama pengurus, dan masih ada anggota yang tidak memenuhi kewajibannya baik membayar simpanan maupun membayar hutangnya hal ini diatasi dengan memberikan surat peringatan. Hal ini dapat dilihat pada tingkat pendapatan koperasi yang semakin menurun

Sementara pada tahun 2015 jumlah kredit simpan pinjam mengalami peningkatan hal ini disebabkan karena kelancaran nasabah membayar kredit, meningkatnya jumlah nasabah dan meningkatnya jumlah kolektor dengan bertambahnya tingkat kebutuhan anggota maka kredit simpan pinjam akan meningkat, karena kredit simpan pinjam merupakan salah satu kegiatan usaha yang ada dikoperasi yang akan menghasilkan pendapatan koperasi. Pendapatan koperasi 
Jurnal of Applied Business and Banking (JABB) Vol 2 No 1 Maret 2021

E-ISSN 2723-634X P-ISSN 2775-622X

J. KH. Ahmad Dahlan No.1, Pagesangan, Kec. Mataram, Kota Mataram, Nusa Tenggara Barat yang terhimpun pada koperasi Damai periode 2015-2019 mengalami penurunan dari tahun ke tahun hal ini disebabkan oleh transaksi keuangan terkadang tidak tepat waktu dan masih ada anggota yang tidak memenuhi kewajibannya baik membayar hutangnya. Sementara pada tahun 2015 jumlah pendapatan mengalami peningkatan.

Berangkat dari fenomena yang telah dikemukakan, dan belum ada penelitian yang mengkaji tentang pengaruh kredit koperasi Simpan Pinjam Terhadap peningkatan Pendapatan anggota Koperasi simpan pinjam Damaikecamatan gangga kabupaten lombok utara, maka menimbulkan ketertarikan penulis untuk mengangkat tema ini menjadi suatu kajian empirik. Berdasarkan uraian latar belakang diatas, masalah yang dapat dirumuskan dalam penelitian ini adalah :

1. Pengaruh Kredit Koperasi Simpan Pinjam Terhadap Peningkatan Pendapatan Anggota Koperasi Simpan Pinjam (KSP) Damai Kecamatan Gangga Kabupaten Lombok Utara ?

\section{LANDASAN TEORI}

Pengertian menurut undang-undang No 10 tahun 1998 (UU Perbankan) adalah penyediaan uang atau tagihan yang dapat disalurkan, berdasarkan persetujuan pinjam meminjam antara pihak bank dengan pihak peminjam untuk melunasi hutangnya setelah jangka waktu tertentu dengan jumlah bunga, imbalan atau hasil keuntungan. Pengertian menurut Muhcdarsyah Sinungan (1995: 3) kredit adalah suatu pemberian prestasi oleh suatu pihak dengan pihak lain dan prestasi itu dikembalikan lagi pada suatu masa tertentu yang akan datang di sertai dengan kontra prestasi berupa bunga.Dari beberapa pengertian diatas dapat diambil kesimpulan bahwa kredit adalah sebuah perjanjian pembayaran yang berupa uang, benda atau jasa yang diterima pada masa sekarang dan kontra prestasinya pada masa yang akan datang.

Menurut Undang-Undang Nomor 25 Tahun 1992 tentang pokok-pokok perkoperasian maka dikenal dengan jenis-jenis koperasi antara lain koperasi konsumsi, koperasi produksi, koperasi simpan pinjam (KSP)/kredit, koperasi jasa dan koperasi serba usaha. Kabupaten lombok utara merupakan salah satu Kabupaten yang ada di Provinsi Nusa Tenggara Barat dimana perkembangan koperasi di Kabupaten Lombok Utara cukup baik dengan peningkatan jumlah koperasi setiap tahunnya. Tujuan kredit yang di berikan yaitu memperoleh keuntungan sehingga 

meneruskan simpanan pada orang lain dalam bentuk kredit, jika nasabah atau anggota diyakini dapat mangembalikan kredit yang telah diterimanya dari faktor kemauan tersebut tersimpul dua unsur yang saling berkaitan.

Sedangkan fungsi kredit menurut Baswir adalah :

1. Kredit dapat meningkatkan daya guna modal keuangan atau uang. Para pemilik uang atau modal dapat secara langsung meminjamkan uangnya kepada para pengusaha yang memerlukan untuk meningkatkan produksi atau meningkatkan usahanya, selain itu para pemilik modal juga dapat menyimpan uangnya pada lembaga keuangan. Uang tersebut digunakan sebagai pinjaman para pengusaha-pengusaha.

2. Kredit dapat meningkatkan peredaran dan lalu lintas uang. Kredit uang yang disalurkan melalui rekening giro dapat menciptakan pembayaran baru seperti cek, giro bilyet, wesel sehingga bila pembayaran-pembayaran dilakukan dengan cek, giro bilyet dan wesel akan dapat meningkatkan peredaran uang giral sehingga kredit perbankkan yang ditarik secara tunai dapat pula meningkatkan uang kartal, sehingga arus lalu-lintas uang akan berkembang.

3. Kredit dapat pula meningkatkan peredaran dan daya guna barang. Dengan mendapatkan kredit para pengusaha dapat memproses bahan baku menjadi barang jadi sehingga daya guna barang tersebut menjadi meningkat. Disamping itu pula kredit dapat meningkatkan peredaran barang baik melalui penjualan barang secara kredit maupun dengan membeli barang dari suatu tempat dan menjual ke tempat lain yang mana pembelian tersebut uangnya dari kredit sehingga dalam hal ini kredit dapat pula meningkatkan suatu barang.

4. Kredit sebagai salah satu alat stabilitas ekonomi. Dalam keadaan ekonomi yang kurang sehat kebijakan diarahkan kepada usaha-usaha

Jenis- jenis kredit menurut Tjoekam Moch.

1. jenis - jenis kredit menurut segi penggunaannya dibedakan menjadi :

a. Kredit konsumtif

Kredit ini dipergunakan untuk keperluan konsumsi bagi peminjam artinya uang kredit akan habis untuk memenuhi kebutuhannya.

b. Kredit produktif. 
Kredit ini di tujukan untuk keperluan peningkatan usaha baik usaha produktif, perdagangan atau investasi.

c. Kredit semi konsumtif dan kredit semi produktif.

2. jenis-jenis kredit menurut segi penggunaan.

a. Kredit produksi atau eksploitasi

Kredit ini di perlukan perusahaan untuk meningkatkan produksi baik peningkatan kualitatif yaitu peningkatan kualitas atau mutu hasil produksi maupun peningkatan kuantitatif yaitu jumlah hasil produksi.

b. Kredit perdagangan

Kredit ini dipergunakan untuk keperluan perdagangan pada umumnya yang berarti peningkatan kegunaan tempat (utility of place) dari suatu barang.

c. Kredit investasi

Kredit ini dipergunakan untuk keperluan investasi yaitu penanaman modal

d. Kredit usaha kecil

Kredit ini di berikan kepada pedagang golongan menengah ke bawah.

e. Kredit modal kerja .

Kredit yang diberikan untuk tujuan modal usaha.

f. Kredit likuiditas bank Indonesia

Kredit dari bank Indonesia yang di peruntukkan bagi bank bank pemerintah dan bank swasta guna disalurkan untuk berbagai sektor.

g. Kredit pinjaman konsumen

Kredit yang diberikan untuk tujuan konsumtif.

3. Jenis - Jenis kredit menurut jangka waktunya.

a. Kredit jangka pendek

Kredit yang berjangka waktu selama- lamanya 1 tahun.

b. Kredit jangka menengah

Kredit yang berjangka waktu antara 1 tahun sampai 3 tahun.

c. Kredit jangka panjang

Kredit yang jangka waktunya melebihi jangka waktu 3 tahun.

4. jenis - jenis kredit menurut cara pemakaiannya 
a. Kredit rekening Koran bebas

Dalam sistem ini nasabah bebas melakukan penarikan uang ke dalam rekening yang bersangkutan selama kredit berjalan.

b. Kredit rekening Koran terbatas

Dalam sistem ini terdapat suatu pembatasan tertentu bagi nasabah dalam melakukan penarikan-penarikan uang melalui rekening uang yang dimiliki.

c. Rekening Koran afolopend

Adalah penarikan kredit yang dilakukan sekaligus dalam arti seluruh maksimum kredit pada waktu penarikan pertama digunakan oleh nasabah.

d. Refolving credit

Pada dasarnya refolving credit ini sama dengan kredit rekening Koran hanya saja cara pemakaiannya yang berbeda.

e. Temloan

Temloan adalah kredit yang di berikan untuk meningkatkan usaha Kredit ini ditujukan untuk peningkatan usaha dalam arti untuk keperluan produksi atau perdagangan baik untuk pembelian bahan-bahan baku atau perdagangan sesuai dengan uraian keperluan kredit dalam perjanjian kredit.

5. jenis - jenis kredit menurut jaminannya

a. Unsecured loans

Kredit yang diberikan tanpa menggunakan jaminan

b. Secured loans

Kredit yang diberikan dengan menggunakan jaminan

6. jenis - jenis kredit dilihat dari segi dokumen

a. Kredit ekspor

Adalah semua bentuk kredit sebagai sumber pembiayaan bagi usaha ekspor.

b. Kredit impor

Adalah semua bentuk kredit sebagai sumber pembiayaan bagi usaha impor.

7. jenis- jenis kredit dari segi besar kecilnya aktifitas pemutaran usaha.

a. Kredit kecil

Kredit yang diberikan kepada pengusaha yang tergolong kecil. 
b. Kredit menengah

Kredit yang diberikan kepada pengusaha yang tergolong menengah.

\section{c. Kredit besar}

Kredit yang diberikan kepada pengusaha yang tergolong besar (Tjoekam, 1999: 89-110).

Pendapatan adalah peningkatan jumlah aktiva atau penurunan kewajiban suatu badan usaha yang timbul dari penyerahan barang atau jasa atau aktivitas usaha lainnya dalam suatu periode (Ikatan Akutansi Indonesia). Setiap orang selalu ingin memenuhi kebutuhannya. Untuk dapat memenuhi kebutuhannya diperlukan suatu pekerjaan dan usaha. Karrena dengan bekerja dan berusaha akan mendapatkan penghasilan atau pendapatan yang dapat digunakan untuk memenuhi kebutuhan hidup seperti kebutuhan akan makan, pakaian, perumahan, pendidikan dan kebutuhan kesehatan. Seseorang dapat memperoleh pendapatan dengan jalan bekerja maupun dari harta benda yang dimiliki misalnya tanah, mesin, rumah, atau yang lainnya yang disebut barang modal (Sumardi. $1985: 16$ ).

Menurut Kuswanto Putro pendapatan adalah semua penghasilan yang diterima oleh orang dalam kegiatan ekonomi dalam suatu periode (1995 : 24). Dari pengertian tersebut dapat diambil kesimpulan bahwa pendapatan adalah semua penghasilan yang diterima oleh pemilik faktor produksi dalam suatu periode.

Pendapatan dibedakan menjadi tiga bagian yaitu :

\section{a.) Pendapatan berupa uang}

Pendapatan berupa uang adalah segala penghasilan berupa uang yang sifatnya regular dan yang diterima biasanya sebagai balas jasa atau kontra prestasi. Sumber - sumber yang utama adalah gaji dan upah serta lain - lain balas jasa serupa dari majikan,pendapatan bersih dari usaha sendiri dan pekerjaan bebas, pendapatan dari penjualan barang yang diperilahra di rumah, hasil investasi seperti bunga modal, tanah, uang pensiun, jaminan sosial serta keuntungan sosial.

b.) Pendapatan berupa barang

Pendapatan berupa barang adalah segala penghasilan yang sifatnya regular dan biasa akan tetapi tidak selalu berbentuk balas jasa dan diterima dalam bentuk barang atau jasa. Barang - barang dan jasa yang diperoleh dinilai dengan harga pasar sekalipun tidak diimbangi atau 

disertai transaksi uang oleh yang menikmati barang dan jasa. Demikian pula penerimaan barang secara Cuma - Cuma pembelian barang dan jasa dengan harga subsidi atau reduksi dari majikan merupakan pendapatan berupa barang.

c.) Lain - lain penerimaan uang dan barang

Merupakan segala penerimaan yang bersinfat transfer redistributif dan biasanya membawa perubahan dalam keuangan rumah tangga misalnya penjualan barang - barang yang dipakai, pinjaman uang, hasil undian, warisan, penagihan piutang, kiriman uang.

Kredit simpan pinjam pada Koperasi Damai pada tahun 2015 sampai dengan tahun 2019 terus mengalami penurunan, yakni pada tahun 2016 kredit simpan pinjam pada Koperasi Damai mengalami penurunan. Selanjutnya pada tahun 2017 kredit simpan pinjam pada Koperasi Damai mengalami penurunan kembali. Pada tahun 2018 kredit simpan pinjam pada Koperasi damai kembali mengalami penurunan.

Selanjutnya pada tahun 2019 kredit simpan pinjam kembali mengalami penurunan. Hal ini disebabkan oleh beberapa faktor, yakni karena pencatatan transaksi keuangan terkadang tidak tepat waktu hal ini karena disebabkan karena kesibukan yang dihadapi pengurus hal ini dapat diatasi dengan kerjasama pengurus, dan masih ada anggota yang tidak memenuhi kewajibannya baik membayar simpanan maupun membayar hutangnya hal ini diatasi dengan memberikan surat peringatan. Hal ini dapat dilihat pada tingkat pendapatan koperasi yang semakin menurun.

Adanya kredit yang macet sangat berpengaruh terhadap menurunnya jumlah kredit yang disalurkan karena kredit yang diberikan tidak bisa kembali, dimana hal ini sangat berpengaruh terhadap modal koperasi untuk menyalurkan dana untuk usaha simpan pinjam. Macetnya kredit merupakan faktor utama menurunnya jumlah kredit simpan pinjam pada Koperasi damai. Selanjutnya adalah persaingan dengan koperasi lainnya. Adanya persaingan dengan koperasi lainnya merupakan hal selanjutnya yang mempengaruhi menurunnya kredit simpan pinjam pada Koperasi Damai karena dari persaingan tersebut, nasabah beralih mencari kredit/pinjaman dengan syarat yang mungkin dianggap lebih mudah dibanding dengan syarat kredit pada Koperasi Damai. 
Jurnal of Applied Business and Banking (JABB) Vol 2 No 1 Maret 2021

E-ISSN 2723-634X P-ISSN 2775-622X

Jl. KH. Ahmad Dahlan No.1, Pagesangan, Kec. Mataram, Kota Mataram, Nusa Tenggara Barat Hipotesis adalah jawaban sementara terhadap tujuan penelitian yang diturunkan dari kerangka pemikiran yang telah dibuat. Hipotesis merupakan pernyataan belum pasti tentang hubungan antara beberapa dua variabel atau lebih. Pada penelitian kuantitatif hipotesis lazim dituliskan dalam sub- bab tersendiri. Hipotesis merupakan dugaan sementara dari jawaban rumusan masalah penelitian dimana hipotesis nol atau tidak berpengaruh dilambangkan dengan H0 dan hipotesis alternatife atau berpengaruh dilambangkan dengan Ha.

Berdasarkan kerangka pemikiran dan penelitian sebelumnya yang menyatakan bahwa pengaruh kredit koperasi simpan pinjam terhadap peningkatan pendapatan anggota koperasi simpan pinjam di atas, maka dapat diajukan hipotesis penelitian sebagai berikut :

Hipotesis :

Diduga ada pengaruh kredit koperasi simpan pinjam terhadap peningkatan pendapatan anggota koperasi simpan pinjam (KSP) Damai kecamatan gangga kabupaten lombok utara ?

Ho = Variabel kredit koperasi tidak berpengaruh secara segnifikan terhadap peningkatan pendapatan anggota KSP Damai

$\mathrm{Ha}=$ Variabel kredit koperasi berpengaruh secara segnifikan terhadap peningkatan pendapatan anggota KSP Damai

\section{METODE PENELITIAN}

Adapun metode yang digunakan Jenis penelitian yang digunakan adalah penelitian kuantitatif. Penelitian kuantitatif adalah penelitian yang banyak menuntut penggunaan angka, mulai dari pengumpulan data, penafsiran terhadap data tersebut, serta penampilan dari hasilnya. Demikian pula pada tahap kesimpulan penelitian akan lebih baik bila disertai dengan gambar, tabel, grafik atau tampilan lainnya.

Menurut Sugiyono, metode penelitian kuantitatif dapat diartikan sebagai metode penelitian yang berlandaskan pada filsafat positivism, digunakan untuk meneliti pada populasi atau sampel tertentu. Teknik pengambilan sampel pada umumnya dilakukan secara random, pengumpulan data menggunakan instrument penelitian, analisis data bersifat kuantitatif / statistic dengan tujuan untuk menguji hipotesis yang telah ditetapkan (sugiyono, $2012: 7$ )

Penelitian kuantitatif yaitu penelitian yang bertujuan untuk menemukan ada tidaknya pengaruh kredit simpan pinjam terhadap peningkatanpendapatan koperasi pada Koperasi simpan pinjam Damai Kabupaten lombok utara. Dan menggunakan pendekatan kuantitatif karena 
Jurnal of Applied Business and Banking (JABB) Vol 2 No 1 Maret 2021

E-ISSN 2723-634X P-ISSN 2775-622X

Jl. KH. Ahmad Dahlan No.1, Pagesangan, Kec. Mataram, Kota Mataram, Nusa Tenggara Barat variabel bebas dan variabel terikat diukur dalam bentuk angka-angka, dan kemudian dicari ada tidaknya pengaruh antara kedua variabel terebut. Data Reduksi (Data Reduction), dengan peralatan elektronik seperti komputer mini, dengan memberikan kode pada aspek-aspek tertentu.

\section{HASIL DAN PEMBAHASAN}

Koperasi Damai berdiri pada tanggal 29 November tahun 1975 dengan badan hukum No. 649.b/BH/XXII, 1975. Pada mulanya koperasi Damai dikenal dengan nama Kesra dan pendiri koperasi pertama kali yaitu yahya dan sekarang yang kemudian digantikan oleh ahmad abdul ghani. setiap 5 tahun sekali pergantian pimpinan sekaligus pengurus koperasi dan pergantian anggota setiap 3 bulan sekali. Kopersi Damai merupakan suatu perkumpulan dengan usaha simpan pinjam bagi pegawai negeri sipil tersebut. Kemudian berkembang menjadi lebih baik dan memperluas usaha dengan tujuan untuk meningkatkan kesejahteraan anggotanya pada khususn ya dan masyarakat pada umumnya.

Kewajiban pengurus terhadap anggota yang mengalami musibah dan pensiun tetap menjadi prioritas utama, hal ini merupakan amanat dari program kerja koperasi Terhadap anggota yang kreditnya macet. Tugas Dan Tanggung Jawab Pengurus Dan Pengawas Koperasi Simpan Pinjam Damai Masing - masing pengurus akan mempunyai tugas dan wewenang yang sudah diatur dalam panduan kerja pengurus dan staf koperasi sebagai pedoman kerjanya. Tugas dan wewenang tersebut antara lain : Pengawas bertugas untuk mengawasi, mengontrol, dan meningkatkan setiap kinerja pengurus dalam menjalankan organisasi. Dalam hal ini pengawas melakukan pengawasan terhadap semua kebijaksanaan operasional pengurus yang meliputi bidang organisasi, usaha dan keuangan koperasi (Sumber : Panduan Kerja Pengurus dan Staf Koperasi damai).

Berdasarkan output diketahui angka $\mathrm{r}$ hitung untuk kredit 1 adalah sebesar 0,237, kredit 2 sebesar 0,529, kredit 3 sebesar 0,721, kredit 4 sebesar 0,644, kredit 5 sebesar 0,716, hasil tersebut menunjukkan pertanyaan no 1 sampai no 5 adalah valid karena nilai $r$ hitung lebih besar dari r tabel sebesar 0,05 Uji Reliabilitas Berdasarkan hasil pengujian reliabilitas diketahui angka cronchbach alpha adalah sebesar 0,533. Jadi angka tersebut $(0,533)$ lebih besar dari nilai minimal 

crochbach alpha 0,05. Oleh karena itu dapat disimpulkan bahwa instrumen penelitian yang digunakan untuk mengukur variable kredit dapat dikatakan reliable atau handal Hasil Uji Hipotesis. Berdasarkan output diketahui nilai t hitung sebesar 2.579 karena nilai t hitung sudah ditemukan, maka langkah selanjutnya kita akan mencari nilai t tabel. Adapun rumus dalam mencari t tabel adalah

Nilai a $/ 2=0,05 / 2=0,025$ Derajad kebebasan $(\mathrm{df})=\mathrm{n}-2=50-2=48=2,01063$

Nilai 0,025 ; 48 kemudian kita lihat pada distribusi nilai t tabel maka di dapat nilai t tabel sebesar 2,01063 Karena nilai t hitung sebesar 2.579 lebih besar dari < 2,01063, sehingga dapat disimpulkan bahwa H0 ditolak dan Ha diterima yang berarti bahwa "ada pengaruh kredit koperasi (X) terhadap pendapatan anggota (Y)”. nilai t hitung 2,579 dianggap lebih besar dari nilai t tabel 2,01063 dalam analisis regresi linear sederhana

Untuk mengetahui besarnya pengaruh kredit koperasi (X) terhadap pendapatan anggota (Y) dalam analisis regresi linear sederhana, kita dapat berpedoman pada nilai R Square atau R2 yang terdapat pada output SPSS bagian Model Summary. Dari output diatas diketahui nilai R Square sebesar 0,122. Nilai ini mengandung arti bahwa pengaruh kredit koperasi (X) terhadap pendapatan anggota (Y) adalah sebesar $12,2 \%$

Hasil penelitian analisis statistik dalam penelitian ini menunjukkan adanya pengaruh antara kredit Koperasi terhadap pendapatan anggota Koperasi Damai. Dari analisis regresi diperoleh angka yang menyatakan bahwa kredit koperasi berpengaruh terhadap pendapatan anggota koperasi yang dibuktikan oleh hasil perhitungan dimana Fhitung > Ftabel $(6,650>0,05)$ dan hasil analisis maka variabel kredit memberikan sumbangan yang cukup terhadap pendapatan anggota koperasi. t hitung sebesar 2.579 lebih besar dari < 2,01063, sehingga dapat disimpulkan bahwa H0 ditolak dan Ha diterima yang berarti bahwa "ada pengaruh kredit koperasi (X) terhadap pendapatan anggota (Y)". nilai t hitung 2,579 dianggap lebih besar dari nilai t tabel 2,01063 dalam analisis regresi linear sederhana. Sedangkan dari output diatas diketahui nilai $\mathrm{R}$ Square sebesar 0,122. Nilai ini mengandung arti bahwa pengaruh kredit koperasi (X) terhadap pendapatan anggota (Y) adalah sebesar 12,2\%. Berdasarkan output diatas diketahui angka $\mathrm{r}$ hitung untuk kredit 1 adalah sebesar 0,237, kredit 2 sebesar 0,529, kredit 3 sebesar 0,721, kredit 
Jurnal of Applied Business and Banking (JABB) Vol 2 No 1 Maret 2021

E-ISSN 2723-634X P-ISSN 2775-622X

JI. KH. Ahmad Dahlan No.1, Pagesangan, Kec. Mataram, Kota Mataram, Nusa Tenggara Barat 4 sebesar 0,644, kredit 5 sebesar 0,716, hasil tersebut menunjukkan pertanyaan no 1 sampai no 5 adalah valid karena nilai $r$ hitung lebih besar dari $r$ tabel sebesar 0,05. Berdasarkan output diatas diketahui angka $\mathrm{r}$ hitung untuk pendapatan 1 adalah sebesar 0,619, Pendapatan 2 sebesar 0,450, pendapatan 3 sebesar 0,279, pendapatan 4 sebesar 0,342, pendapatan 5 sebesar 0,560, hasil tersebut menunjukkan pertanyaan no 1 sampai no 5 adalah valid karena nilai $r$ hitung lebih besar dari r table sebesar 0,05

Berdasarkan hasil pengujian reliabilitas $\mathrm{X}$, diketahui angka cronchbach alpha adalah sebesar 0,533. Jadi angka tersebut $(0,533)$ lebih besar dari nilai minimal cronchbach alpha 0,05. Oleh karena itu dapat disimpulkan bahwa instrumen penelitian yang digunakan untuk mengukur variable kredit dapat dikatakan reliable atau handal. Berdasarkan hasil pengujian reliabilitas diatas, diketahui angka cronchbach alpha adalah sebesar 0,533. Jadi angka tersebut $(0,533)$ lebih besar dari nilai minimal cronchbach alpha 0,05. Oleh karena itu dapat disimpulkan bahwa instrumen penelitian yang digunakan untuk mengukur variable pendapatan dapat dikatakan reliable atau handal. Variabel nilai prediksi mempunyai nilai mean 19,60 dan standar deviasi sebesar 0,564. Hal ini berarti bahwa Nilai mean lebih kecil daripada standar deviasi, sehingga mengindikasikan bahwa hasil yang kurang baik. Sebab standar deviasi merupakan pencerminan penyimpangan yang sangat tinggi sehingga peyebaran data menunjukkan hasil yang tidak normal dan menyebabkan bias. Nilai minimal nilai prediksi sebesar 18,19 dan nilai maksimumnya 20,65. Dengan hasil data tersebut menunjukan bahwa nilai prediksi mengalami fluktuasi / meningkat yang tidak terlalu besar

Variabel sisa mempunyai nilai mean sebesar 0,000 dan standar deviasi (std deviation) sebesar 1.515. hal ini menunjukkan bahwa nilai mean lebih kecil daripada standar deviasi sehingga mengindikasikan bahwa hasil yang kurang baik. Sebab standar deviasi merupakan pencerminan penyimpangan yang sangat tinggi, sehingga penyebaran data menunjukkan hasil yang normal dan tidak menyebabkan bias. Nilai minimumnya sebesar -3.669 dan nilai maksimumnya sebesar 3.068. Variabel standar nilai prediksi mempunyai nilai mean sebesar 0,000 dan standar deviasi (std deviation) sebesar 1.000. hal ini menunjukkan bahwa nilai mean lebih kecil daripada standar deviasi sehingga mengindikasikan bahwa hasil yang kurang baik. Sebab standar deviasi merupakan pencerminan penyimpangan yang sangat tinggi, sehingga 

penyebaran data menunjukkan hasil yang normal dan tidak menyebabkan bias. Nilai minimumnya sebesar -2.492 dan nilai maksimumnya sebesar 1.865 .

Variabel standar sisa mempunyai nilai mean sebesar 0,000 dan standar deviasi (std deviation) sebesar 0,990. hal ini menunjukkan bahwa nilai mean lebih kecil daripada standar deviasi sehingga mengindikasikan bahwa hasil yang kurang baik. Sebab standar deviasi merupakan pencerminan penyimpangan yang sangat tinggi, sehingga penyebaran data menunjukkan hasil yang normal dan tidak menyebabkan bias. Nilai minimumnya sebesar -2.397 dan nilai maksimumnya sebesar 2.005. Kredit yang diberikan oleh koperasi Damai kepada anggota diharapkan dapat digunakan untuk meningkatkan atau mengembangkan usahanya, yang berarti dapat meningkatkan keuntungan yang akan mereka peroleh. Hal ini akan berpengaruh terhadap peningkatan pendapatan. Dengan meningkatnya pendapatan anggota maka pendapatan koperasi akan terus meningkat. Apabila anggota koperasi terus memanfaatkan kredit tersebut untuk pengembangan usahanya. Anggota koperasi dapat menikmati kredit untuk memperbesar usahanya Pada dasarnya kredit bertujuan untuk dapat meningkatkan produktivitas anggota secara menyeluruh. Penggunaan dana kredit yang tidak tepat (tidak produktif) dapat mengakibatkan kerugian yang sangat besar bagi penerima kredit. Disamping mereka mengalami kerugian dalam usahanya, mereka juga harus menanggung pengembalian dana tersebut. Adanya inisiatif sendiri dari anggota menunjukkan bahwa anggota mempunyai pandangan yang positif terhadap kredit yang diberikan oleh koperasi Damai, sehingga mereka mengambil kredit untuk menambah modal kerja dengan harapan dapat mengembangkan usahanya yang pada akhirnya akan meningkatkan pendapatannya. Dengan demikian hipotesis kerja atau dengan kata lain Ha diterima yang berarti ada pengaruh antara kredit koperasi terhadap pendapatan anggota Koperasi Damai di Kabupaten Lombok Utara.

\section{KESIMPULAN}

Berdasarkan hasil analisis yang telah dilakukan dalam bab sebelumnya maka dapat ditarik kesimpulan sebagai berikut :

1. Ada pengaruh antara kredit koperasi terhadap pendapatan anggota Koperasi Damai di Kabupaten Lombok Utara dibuktikan oleh hasil perhitungan dimana Fhitung > Ftabel 
Jurnal of Applied Business and Banking (JABB) Vol 2 No 1 Maret 2021

E-ISSN 2723-634X P-ISSN 2775-622X

J. KH. Ahmad Dahlan No.1, Pagesangan, Kec. Mataram, Kota Mataram, Nusa Tenggara Barat $(6,650>0,05)$ dan hasil analisis maka variabel kredit memberikan sumbangan yang cukup terhadap pendapatan anggota koperasi. t hitung sebesar 2.579 lebih besar dari < 2,01063, sehingga dapat disimpulkan bahwa H0 ditolak dan Ha diterima yang berarti bahwa "ada pengaruh kredit koperasi (X) terhadap pendapatan anggota (Y)". nilai $\mathrm{t}$ hitung 2,579 dianggap lebih besar dari nilai t tabel 2,01063 dalam analisis regresi linear sederhana. Sedangkan dari output diatas diketahui nilai R Square sebesar 0,122. Nilai ini mengandung arti bahwa pengaruh kredit koperasi $(\mathrm{X})$ terhadap pendapatan anggota $(\mathrm{Y})$ adalah sebesar $12,2 \%$.

2. Besarnya sumbangan kredit koperasi terhadap pendapatan anggota Koperasi Damai Kabupaten Lombok Utara cukup besar pengaruhnya karena berdasarkan pendapatan anggota sesudah menerima kredit koperasi mayoritas pendapatan antara 1.000.000 3.000.000, 30 orang $(60,0 \%)$ sedangkan pendapatan antara 3.000.000 - 5.000.000, 20 orang $(40,0 \%)$

Berdasarkan kesimpulan-kesimpulan dan implikasi di atas, maka penulis mengemukakan saransaran sebagai berikut :

\section{a. Bagi Koperasi Simpan Pinjam}

1. Adanya pengaruh kredit yang diberikan terhadap peningkatan pendapatan anggota tersebut hendaknya dapat dijadikan bahan pertimbangan bagi koperasi untuk dapat lebih meningkatkan plafon kredit yang diberikan sesuai dengan kebutuhan anggota (peminjam) dengan tetap berpegang pada prinsip kehatian-hatian

2. kredit hendaknya lebih tepat sasaran, di sini koperasi hendaknya dalam memberikan kredit lebih mengutamakan pemberian kredit primer (kredit yang akan digunakan untuk menambah modal usaha) karena dengan bertambahnya modal usaha diharapkan anggota atau peminjam dapat meningkatkan laba atau keuntungan sehingga akan menambah pendapatan mereka yang pada akhirnya koperasi juga akan menerima keuntungan dari kondisi ini.

3. Perlu adanya kerjasama yang baik antara koperasi dengan anggota dalam hal saling keterbukaan antara pihak pemberian kredit dan penerima. Koperasi tidak hanya berperan dalam melakukan pencairan dan pemberian kredit saja namun juga mampu membantu anggota dalam 

memecahkan masalah yang sedang dihadapi seandainya terjadi kredit macet dan sebaliknya anggota juga harus terbuka dengan permasalahan dan kondisi yang sedang dihadapinya.

4. Pengawas hendaknya dapat berperan aktif terutama dalam pemberian kredit maupun menyikapi adanya kredit macet baik dari anggota maupun dari pihak di luar anggota (umum).

b. Bagi Peneliti

Untuk peneliti selanjutnya diharapkan bisa melakukan penelitian yang lebih mendalam dengan objek maupun sudut pandang yang berbeda lagi untuk meningkatkan wawasan terhadap kredit pendapatan anggota

\section{DAFTAR PUSTAKA}

Sisca Silvia, 2011. 2015. Pengaruh Pemberian Kredit Simpan Pinjam Dan Perputaran Likuiditas Terhadap Pendapatan Koperasi Pada Koperasi Pasar Serbaguna Kabupaten Bungo, Artikel. Jurusan PIPS Fkip.Universitas Jambi. (artikel)

Iyan Rani Rita, Yuliani. 2006. 2010. Peran Kredit Koperasi Simpan Pinjam Terhadap Peningkatan Pendapatan Dan Usaha Anggotanya Dikecamatan Tembilahan Kabupaten Indragiri Hilir, Artikel. Jurusan Ilmu Ekonomi. Universitas Riau. (artikel)

Wandirah Ayu, Dwi Atmaja. Pengaruh Kredit Simpan Pinjam Terhadap Pendapatan Koperasi Tani Satya Jaya Keloncing. Jurnal. Jurusan Akutansi. Universitas FEB Undiksha. (jurnal)

Budianto Nanang, 2005. Pengaruh Pemberian Kredit Produksi Terhadap Pendapatan Anggota Koperasi Banjar Artha Sarana (Bathara) Dikabupaten Banjarnegara, Skripsi. Universitas Negeri Semarang (skripsi)

Pratiwi Salindri Friska, 2009-2013. pengaruh kredit koperasi simpan pinjam terhadap pendapatan koperasi pada KP-RI Abdi wiyata. Jurnal. Jurusan Akutansi Feb Universitas Dian Niswantoro. (jurnal)

Fauziah Rini Firda, 2018. Pengaruh Kualitas Pelayanan Pada Koperasi Simpan Pinjam Pembiayaan Syariah (Kspps) Bmt Dana Li Mardhatillah (Damar) Semarang Terhadap Tingkat 
Jurnal of Applied Business and Banking (JABB) Vol 2 No 1 Maret 2021

E-ISSN 2723-634X P-ISSN 2775-622X

Jl. KH. Ahmad Dahlan No.1, Pagesangan, Kec. Mataram, Kota Mataram, Nusa Tenggara Barat Kepuasan Anggota. Skripsi. Jurusan Manajemen Dakwah. Universitas Islam Negeri Walisongo Semarang. (skripsi)

Budianto Nanang, 2004. Pengaruh Pemberian Kredit Produksi Terhadap Pendapatan Anggota Koperasi Banjar Artha Sarana (Bathara). Skripsi. Universitas negeri Semarang (skripsi)

Rapat Anggota Tahunan (Rat), 2009. Laporan Pertanggungjawaban Pengurus Dan Pengawas Koperasi Pegawai Republik Indonesia Dikabupaten Lombok Utara. (Buku RAT)

Rapat Anggota Tahunan (Rat), 2010. Laporan Pertanggungjawaban Pengurus Dan Pengawas Koperasi Pegawai Republik Indonesia Dikabupaten Lombok Utara. (Buku RAT)

Rapat Anggota Tahunan (Rat), 2011. Laporan Pertanggungjawaban Pengurus Dan Pengawas Koperasi Pegawai Republik Indonesia Dikabupaten Lombok Utara. (Buku RAT)

Rapat Anggota Tahunan (Rat), 2012. Laporan Pertanggungjawaban Pengurus DanPengawas Koperasi Pegawai Republik Indonesia Dikabupaten Lombok Utara.(Buku RAT)

Rapat Anggota Tahunan (Rat), 2013. Laporan Pertanggungjawaban Pengurus Dan Pengawas Koperasi Pegawai Republik Indonesia Dikabupaten Lombok Utara.(Buku RAT)

Rapat Anggota Tahunan (Rat), 2014. Laporan Pertanggungjawaban Pengurus Dan Pengawas Koperasi Pegawai Republik Indonesia Dikabupaten Lombok Utara. (Buku RAT)

Rapat Anggota Tahunan (Rat), 2015. Laporan Pertanggungjawaban Pengurus Dan Pengawas Koperasi Pegawai Republik Indonesia Dikabupaten Lombok Utara.(Buku RAT)

Rapat Anggota Tahunan (Rat), 2016. Laporan Pertanggungjawaban Pengurus Dan Pengawas Koperasi Pegawai Republik Indonesia Dikabupaten Lombok Utara.(Buku RAT)

Rapat Anggota Tahunan (Rat), 2017. Laporan Pertanggungjawaban Pengurus Dan Pengawas Koperasi Pegawai Republik Indonesia Dikabupaten Lombok Utara.(Buku RAT)

Rapat Anggota Tahunan (Rat), 2018. Laporan Pertanggungjawaban Pengurus Dan Pengawas Koperasi Pegawai Republik Indonesia Dikabupaten Lombok Utara.(Buku RAT)

Undang-Undang Republic Indonesia No 17 Tahun 2012 Pasal 4, Perkoperasian 
Undang-Undang No 33 Ayat 1, Perekonomian Indonesia

Rivai Dan Veithzal, 2007, Pengertian Kredit

Marleni, Dkk. 2014.Pengertian Kredit Dan Pendapatan (Pendapat)

Arikunto Suharsmi, 1998 : 31, Pengertian Pengaruh (Pendapat)

Kamus Umum Bahasa Indonesia 1999 : 526, Pengertian Kredit

Ikatan Akutansi Indonesia, 19, Prinsip Akutansi Indonesia, Pengertian Aanggota (Pendapat)

Undang Undang No 10 Tahun 1998, Undang- Umdang Perbankan, Pengertian Kredit

Pendapat Menurut Baswir, Fungsi Kredit

Pendapat Menurut Tjoekam Moch, Jenis-Jenis Kredit

Pendapat Menurut Sumardi, 1985 :16, Pengertian Pendapatan

Pendapat Menurut Kuswanto Putro, 1995 : 24, Pengertian Pendapatan

Pendapat Menurut Dra Niswatin Rakub, 1990 : 5, Fungsi Kredit

Pendapat Menurut Sutrisno Hadi, 1987 : 4, Metode Penelitian

Pendapat Menurut Sugiyono, 2012 : 7, Penelitian Kuantitatif

Pendapat Menurut Sugiyono, $2018:$ 80, Pengertian Populasi

Pendapat Menurut Sugiyono 2014 : 23, Pengertian Jenis Data

Pendapat Menurut Sugiyono 2014 : 61, Definisi Operasional Variable

Pendapat Menurut Suharsmi Arikunto, 1996 : 234, Pengertian Dokumentasi

Pendapat Menurut Suharsmi Arikunto, 1998 : 160, Pengertian Validitas

Pendapat Menurut Sugiyono, 2011, Regresi Sederhana 
Jl. KH. Ahmad Dahlan No.1, Pagesangan, Kec. Mataram, Kota Mataram, Nusa Tenggara Barat Pendapat Menurut Ghozali, 2013 : 98, Uji T

Pendapat Menurut Ghozali, 2013 : 97, Uji R2

Panduan Kerja Pengurus Dan Staf Koperasi Damai

Pendapat Menurut Iqbal, 2008 : 79, Uji Validitas

Pendapat Menurut Ghozali, 2005 : 177, Uji Reliabilitas

Pendapat Menurut Sunyoto, 2011 : 110, Tujuan Uji Normalitas 